\title{
Mostra FSESP - três décadas da experiência Fundação Serviço de Saúde Pública: fragmentos da imagem da educação em saúde
}

\author{
Maria Cristina Soares Guimarães ${ }^{1}$ \\ Cícera Henrique da Silva² \\ Rosinalva Alves de Souza ${ }^{3}$ \\ Rosemary Teixeira dos Santos ${ }^{4}$ \\ Luiza Rosângela da Silva ${ }^{5}$
}

O trabalho de pesquisa para o projeto A Imagem da saúde no discurso oficial do Estado Novo: recuperação e disponibilização do acervo Cinematográfico do SESP - Educação Sanitária em $16 \mathrm{~mm}$, levantou um rico universo imagético e icônico que, para refletir e endossar um projeto de nação, pensou e expôs temas de saúde pública em várias frentes - higiene, epidemiologia, cuidados com alimentação etc. - e para públicos diferentes, articulando ideais de cidadão, de estado, de doença e de saúde em várias mídias. O destaque coube aos curtas e desenhos animados no formato $16 \mathrm{~mm}$, recuperados do acervo original da Serviço Especial de Saúde Pública - SESP para mídia digital, onde estes ideais estão representados ora na temática e nos personagens, ora na própria técnica escolhida para representá-los.

Boa parte do acervo deriva de um momento histórico de convergência entre o interesse do Estado brasileiro e o discurso e o projeto dos Estados Unidos para a América Latina: no escopo de um Acordo Bilateral, foram trazidos para o país filmes educativos, ao mesmo tempo em que técnicos brasileiros produziram e exportaram uma solução fílmica própria, o diafilme. A diversidade de recursos usados e a originalidade de um tipo simpático de cinema no tratamento de questões de difícil compreensão - para um público de diversas idades mas, muitas vezes, iletrado, rural, isolado - inspiraram uma Mostra em que se pudesse apresentar, ao menos, parte do acervo recuperado. Mas a complexidade do contexto histórico, o alcance dos resultados em diversos pontos do país e a articulação com diversos órgãos demandavam o suporte à exibição com fatos e fotos que permitissem ao público entender o que aquele acervo representou durante o apogeu de sua utilização, no Brasil dos anos 1940 e 1950.

Nascia a Mostra FSESP - três décadas da experiência Fundação Serviço de Saúde Pública: fragmentos da imagem da educação em saúde, composta de textos que coordenavam fotos, cartazes e boletins de época e fotogramas do acervo, em módulos ligeiros na forma de pedaços de película retirados de um imaginário rolo gigante de filme, para integrar a programação do $8^{\circ}$ Congresso Regional de Informação em Ciências da Saúde - Crics 2008, no Rio de Janeiro. Foram produzidos cartazes, folhetos e um catálogo para informar o público da Mostra.

O sucesso rendeu vários convites de instituições para que a exposição estivesse presente em seus respectivos eventos. A Mostra Fsesp adquiria, assim, um caráter itinerante que não havia sido pensado.

\footnotetext{
${ }^{1}$ Laboratório de Ciência Tecnologia e Inovação em Saúde, Instituto de Comunicação e Informação Científica e Tecnológica em Saúde, Fundação Oswaldo Cruz (LabCities, Icict/Fiocruz). Av. Brasil, 3865, Rio de Janeiro, RJ, Brasil. 21.040-361.cguima@ icict.fiocruz.br

${ }^{2-5}$ Labcities, Icict, Fiocruz.
} 
Em 2008, a Mostra ilustrou o Seminário SUS 20 anos: desafios para a informação e comunicação em saúde, na Fundação Oswaldo Cruz. Para 2009, planejou-se uma trajetória que incluía percorrer várias cidades - como Outro Preto e Porto Alegre -, mas o surto de gripe suína limitou a Mostra ao IX Congresso Brasileiro de Saúde Coletiva, em Recife. Para 2010, a ideia é traçar um calendário com base na agenda nacional do Ministério da Saúde, mas também abrir espaço aos convites de instituições.

Com a Mostra, a equipe do projeto conseguiu resgatar e dar visibilidade a um período da história da saúde pública brasileira contada de maneira nada usual em imagens em movimento - conhecida, até então, por poucos. A partir dela, e em paralelo à publicação de uma série de artigos que têm a pesquisa como suporte, espera-se estimular pesquisadores e estudantes das mais diversas áreas do conhecimento - História, Ciências Sociais, Saúde, Psicologia, Comunicação, Ciência Política etc. -, que tenham interesse neste objeto, a compartilharem dos achados e prosseguirem produzindo conhecimento sobre eles. 